\title{
Limited Company Beneficial Owner Liability in Criminal Acts of Corruption
}

\author{
Fernando
}

\author{
Research and Development Center Attorney General's Office Republic of Indonesia \\ *Corresponding author. Email: ricercatorelegale@gmail.com
}

\begin{abstract}
Corruption crimes can be committed by forming LLCs for the express purpose of commissioning corruption crimes and then disguising or disguising the proceeds of such crimes for profit. As was later determined by international bodies such as the OECD, the FATF and the G20, LLC was used by the so-called beneficial owner. Determining the beneficial owner of an LLC's liability for illegal conduct is not an easy task, but it is not impossible. The purpose of this study was to assess how beneficial ownership systems are implemented both internationally and locally, and how the beneficial owner should be held accountable for all criminal activity committed by the LLC. The researcher identifies and examines the difficulties qualitatively using a normative research approach based on statutory, case-related and conceptual approaches. This study concluded that the OECD Model Treaty, the FATF Guidelines and the G20 High Level Principles all contain a provision to determine the beneficial owners of international organizations. In Indonesia, it has been incorporated into several laws, including the Investment, Limited Liability Companies, and General Provisions and Tax Procedures Acts, as well as OJK Regulations, Presidential Decree, and the Minister of Law and Human Rights Regulations. To answer the beneficial owner of an LLC for a corrupt act, the LLC must first be identified as a suspect/accused so law enforcementofficers can investigate and seize assets. Once this has been completed, the prosecution can arrest these perpetrators using the means of the anti- money laundering act.
\end{abstract}

Keywords: Beneficial Owner; Limited Liability Company; Corruption

\section{INTRODUCTION}

Corporations are one method for economic players to address their issues and get cash as company capital.[1] Corporations are important for both human and government interests. To satisfy human needs in a nation, business cannot bedivorced from social life. Additionally, businesses are seen as critical to the country's economic structure. The business sector is critical to a country's economic development since it may increase government income via taxes, job creation, technology transfer, and even through businesses such as banks that are strategically essential to Indonesia's economy.[2]

The significance of the business's existence is consistent with Wesley B. Truitt's assertion that the corporation is an artificial entity. Their existence is fictitious and imperceptible. Even yet, businesses are regarded as if they were actual people. Businesses are endowed with this capacity, which enables them to participate in any action that a human would engage in to accomplish their stated objective. Its operations include purchasing and selling things and property, engaging into contracts, borrowing, litigating and being sued, and employing and dismissing workers.[3]

Ironically, the presence of companies in Indonesia has recently been associated with breaches of, if not outright acts against, the law, including the commission of economic and financial crimes, as well as other crimes.[4] Hundreds of companies have been found to be guilty of environmental pollution and unfair commercial rivalry tactics, and more are being investigated. Many companies have also been found to have engaged in criminal activity in the economic sphere, suchas tax evasion, as was the case with PT Asian Agri Group, and corruption, as was the case with PT Giri Jaladhi Wana.

Economic and financial crimes perpetrated by these corporations not only cause damage to people and the broader public, but they also have a negative impact on the state's budget.

Corporations that conduct these infractions or crimes often take the shape of a Limited Liability Company (LLC) or PT in Indonesia, which was formed specifically to commit crimes andconceal and conceal the profits of crime for the benefit of the true "mastermind." This is accomplished by structuring the 
shareownership structure in such a manner that it is difficult for lawenforcement to monitor or trace.[5] The corporate model with beneficial ownership that is not contained in the formation deed or management structure is not yet governed by existing legislation, notably Act Number 40 of 2007 (LLC Act), specifically as the corporation's real beneficiary, or beneficial owner.[6] The presence of these beneficial owners is verydifficult to detect since they are concealed inside the company'sbuilding complex, rendering them legally unidentifiable. Such circumstances make it difficult to identify who is really accountable. It must be acknowledged that identifying a corporation's beneficial owner is very complex.

The importance of disclosing the beneficial owner is actually closely related to the "panama papers" scandal,[7] which subsequently served as an empirical basis for the company's disclosure efforts and efforts in many nations. The world community has taken notice of this controversy since it involves politicians, businesspeople, and government officials from a variety of nations, including Indonesia.[8] Internationally, and long before the scandal broke, the phrase beneficial owner was adopted in the Organization for Economic Cooperation and Development's (OECD) 1977 Model Tax Convention on Income and Capital. Although the word is not defined specifically, it is included in the requirements of Article 10 addressing dividends, Article 11 concerning interest, and Article 12 involving royalties.[9]

The Financial Action Task Force (FATF) started focusing on beneficial owners in 2003, highlighting the need of authorities in a responsible organization or institution in a nation having access to information on company beneficial owners in order to conduct investigations and prosecutions.[10] The FATF then published disclosure guidelines in 2014 that established criteria for beneficial owner transparency, with the goal of preventing and resolving corporate wrongdoing. As part of the FATF's recommendations, nations should guarantee that mechanisms for supplying such information are in place so that accurate andtimely information about corporate beneficial owners is readilyaccessible. The FATF's transparency and beneficial owner criterion is intended to prevent companies from being used for money laundering or terrorist funding. Additionally, this FATF standard supports efforts to avoid and detect other specified platforms so that severe problems like as corruption may be dealt with more efficiently.

The determination and legal process brought against the beneficial owner of a corporation in connection with a criminal act of corruption are critical because they enable law enforcers to track down assets obtained through a criminal act of corruption that are undoubtedly 'enjoyed' by the beneficialowners. In several instances, it turns out that both the Corruption Eradication Commission (KPK) and the Prosecutor's Office arequite 'satisfied' if they are able to hold corrupt corporate executives accountable, despite the fact that one of the primary objectives of anti-corruption law enforcement is to restore state finances, one of which is accomplished through the recovery ofstate assets.

Criminals conceal their beneficial owner status via specific connections with the LLC they manage. As a result, one of theprimary issues that arise when a beneficial owner of an LLC commits a crime is their responsibility. This is because the beneficial owner is not a member of the board of directors, commissioners, or shareholders, but has the ability to control or order the LLC to conduct crimes. Until now, when an LLC commits a crime, only the LLC's board of directors and board of commissioners (often referred to as the LLC's controllers by law enforcement) have been held criminally liable, and have not directly regulated the beneficial owner's liability as the 'mastermind' or perpetrator of the LLC and its organs.

The issue in this study may be framed as how to identify the beneficial owner determination in international organizations and in Indonesia, based on the preceding background description. How is the beneficial owner's responsibility in a limited liability corporation affected by corruption? The goal of this study is to find out and analyze the arrangements for determining beneficial owners in international and Indonesian organizations, as well as to analyze and examine the liability of the beneficial owner of a limited liability company in corruption, based on the formulation of the problem.

\section{METHODS}

The type of research used by the authors in this study is a type of juridical-normative research. The research approach in this study is a statutory and concept approach. The juridical- normative research method is research in which the objects are statutory regulations and library materials

\section{RESULTS AND DISCUSSION}

\subsection{Theoretical Review}

The paradigm utilized in this research is founded on the assumption that individuals, or humans, have their own ideas, and that people are accountable for their own free action. Another hypothesis is that people's voluntary conduct typically reflects their mental condition. A corporation is unquestionably distinct. A corporation is basically a legal formation without a uniform state 
of mind, since it is made up of people, money, assets or property, and contractually established legal rights. It may be difficult to determine a legal entity's precise objectives at any one moment. Only humans, both physically and intellectually, can perform an act or action. The Company, as a 'legal person,' is distinct from its agents, notably directors and commissioners, as well as shareholders. The beneficial owner then uses this loophole to channel his malevolent intents.

For criminal law, this is an issue. Almost every major crimehas a mental component. The difference between borrowing and stealing, or between gifts and bribes, is determined by the defendant's state of mind. England law established the idea of 'directing mind and will,' also known as the identification doctrine, in search of a theory through which corporations may be held liable for the acts of its organs. The guiding mind and conduct (directing mind and will) of the company's organs, including directors, commissioners, and shareholders, is known as the beneficial owner. As a result, the beneficial owner has authority over all of the company's activities and actions performed via the company's organs.

This concept originated in the 1915 English civil case of Lennard Carrying Co. Ltd. v Asiatic Petroleum Co. Ltd., in which the judge in the House of Lords determined that an act by a company's highest authority (executive director or controlling officer) constituted an act of the corporation itself.[11] The identification of the actions of the controlling official with the corporation was then applied to the realm of criminal law in two cases in the 1940s. This approach offers a "breakthrough" for the Public Prosecutor in terms of indicting and punishing companies for crimes that do not fall within the purview of negligence or strict responsibility.

\subsection{Concept and Regulations for Determination of Beneficial Owner}

The beneficial owner is conceptually derived from a trust institution in the first place. The fact that two individuals are engaged in it or that it is in the hands of legal subjects is one of the features of trusts that is known as dual ownership. When a property is transferred to a trustee, there are two types of owners: Beneficial Owners and Equity owners. Beneficial owners are those who receive benefits from or enjoy the object after it hasbeen transferred to the trustee, and equity owners are those whoown a portion of the property but do not have legal ownership of it. Because of this, the trustee is the only person who may bring legal proceedings or take acts directed at or connected to theownership of things under common law principles.[12]
Beneficiaries in common law do not always include owners with trust rights. Thus, the idea of trust establishes two distinctkinds of ownership: legal ownership (owners who are officially registered) and beneficial ownership (parties who enjoy economic benefits from objects owned by legal owners). Using the idea of trusts as a starting point, a system including one or more components termed equity gave rise to the concept of Beneficial Ownership.

The tax treaty between the United States and Canada, agreedin 1942, was the first to establish the idea of a beneficial ownership arrangement. Despite the fact that the agreement incorporates many beneficial ownership principles, it does not restrict the subsidiary's duty to participate in intra-group dividends and does not prohibit the withholding of tax payments arising from dividends by the parent company. It is considered asubsidiary of a business if the shares of that company are held by another company that has voting rights and that company earns a maximum of 25 percent of its revenues from sources other than the subsidiary.

According to an explanatory note to the protocol, the United States and the United Kingdom signed a tax treaty in 1966 that included the concept of Beneficial Ownership. [13] Accordingto the protocol, tax exemptions on dividends, interest, and royalties in the source country of income will no longer be dependent on whether the recipient is taxed in another country, but will be subject to the requirement that the income or income be beneficially owned by a resident of the other country.[14] Because both nations share the same legal system, it is reasonable to infer that the term "beneficial ownership" under this Protocol has the same meaning as it does in the common law setting. To put it another way, the Beneficial Owner is a notionthat arises from the legal institution of trust, with the original agreement being codified in tax law.

Several international laws govern the determination of the beneficial owner, including the FATF Guidelines on Disclosure and Beneficial Ownership and the G20 Goal Principles Towards Beneficial Owner Disclosure:

\section{OECD Tax Convention Model[9]}

The OECD originally established the beneficial owner idea in 1977 with the Model Tax Convention. In 1986, the OECD published a study titled Double Taxation Convention on the Use of Conduit Companies in whichit addressed the beneficial owner once again. The OECD Fiscal Affairs Committee aims to prohibit the awarding of tax treaties to parties that are not entitled to them by excluding Conduit Companies from beneficial owners. Conduit Companies act as middlemen between income receivers and payers. 
Furthermore, giving permission to enter into agreements or fulfill obligations is essentially the same as carrying out the parent company's administrative or fiduciary responsibilities (with very limited authority from the legal owner). The OECD Board of Governors adopted an amendment to the OECD Model in 2014, based on a recommendation from the OECD Committee on Fiscal Affairs to clarify the Beneficial Owner interpretation. The OECD Model for 2014 incorporates suggested modifications to the OECD Comment Model for 2012. It is essential to comprehend them in order to explain the concept of beneficial owner. This clarification suggests revising the comments on Articles 10, 11, and 12 by eliminating the term "complete right to use and enjoy" in favor of a statement that more properly reflects the circumstances in which rights are limited. This clause indicates that there must be nocontractual duty to fulfill the beneficial owner's needs.

\section{FATF Beneficial Owner Disclosure Guidelines}

According to the FATF's 40 Recommendations from 2003, Beneficial Owner refers to a person who, in general, is the owner or controlling person of a company and who conducts transactions on behalf of customers or third parties. It is also regarded to have the greatest effective control if the legal person or legal arrangement in question is controlled by those who really execute thetask at hand. According to the FATF, there are two kinds of beneficial ownership that are recognized: legal persons and legal arrangements.[15] Basic definitions of individuals are as follows: anyone who owns and uses the capital or assets of a legal entity (rather than the legal entity itself); anyone who actually exercises effective control over the legal entity (regardless of whether they hold a formal position within the legal entity); andanyone who is not only legally entitled to do so (individuals or legal entities).

3. G20 High-Level Principles on Disclosure of BeneficialOwner Information

The G20, or the Group of 20 main global economies, had a meeting in Brisbane in 2014, during which the principles of beneficial owner disclosure were formally endorsed. A high priority concern, according to the FATF's 40 Recommendations 2003, is beneficial owner transparency. This is especially true about the requirement for a competent body that has complete access to information on beneficial owners for the purposes of investigation and prosecution of cases.[10] G20 nations have vowed to create a precedent for other countries across the globe by adopting a set of principles relating to beneficial owner disclosure and enacting relevant legislative rules for all of their countries' citizens. A range of international tools and standards areused to establish these principles and to adapt them to the various legal and constitutional frameworks that exist in different nations throughout the world. Each member of the G20 will be given a score based on how well they have implemented these concepts in their own countries. The United Kingdom ranks first in the world when it comes to getting access to important public information. Indonesia is in a medium frame state, with high expectations placed on financial institutions, as a result of the need for accuracy and verification of supporting papers in order to identify financial institution clients. Non-financial institutions, on the other hand, need beneficial owner information, identity, and access in order to operate.[16]

Numerous sections in Indonesian national laws and regulations define what or who is meant by a Beneficial Owner. The following laws and regulations apply:

\section{Investment Law}

Indonesia bans the practice of borrowing names involving nominees and beneficial owners in accordance with the requirements of this legislation. Accordingly, alimited liability corporation that is normatively held by one person but is in reality significantly or substantially owned by another will be prevented from forming in the first place (beneficial owner). Since the implementation of this law, the nominee agreement has frequently evolved from what was previously made directly between the nominee and the beneficial owner to an indirect process with the goal of concealing or hiding the nominee agreement that has actually occurred since the implementation of this law. The issue is that as soon as the nominee company was established, it was found that there was no paperwork or deed indicating that the shares were held by any other entity other than the nominee company, which created a red flag. Due to a cancellation by the nominee, which was made in accordance with the agreemen between the nominee and the beneficial owner, this has occurred.

\section{LLC Act}

Because the definition of shareholders in a Limited Liability Company is unclear under this legislation, nominee shareholders are often employed in place of real shareholders in order to increase the effectiveness of the company. When you become a shareholder in a limited liability company, the nominee agreement 
contains a confirmation that your share ownership is owned and held by another individual. There is no specific wording in Article 48 paragraph (1); the only thing that is stated is that "Company shares are issued in the name of the owner." The following is stated in the explanation: "What is meant by this clause is that the Company is only permitted to issue shares on behalf of the owner and that the Company is not permitted to issue shares on appointment." Without clarity about the agreement of candidates, it is often returned on the basis of contract freedom, as defined in Article 1338 of the Civil Code.

\section{Tax Law}

The term beneficial owner has been regulated since the enactment of Act Number 36 of 2008, namely in Article26 paragraph (1a) and its explanation. In particular, thislaw does not specify how the beneficial owner can be determined and responsible in the event of a tax crime. Beneficial owners can be held accountable if they violate the provisions in Article 43 paragraph (1). As the beneficiary of the tax treaty, the beneficial owner has the power to control the company and give instructions to do or not to do something that is considered a crime in the tax provisions. The LLC that issues shares is not on behalf of the owner, but on behalf of the nominee who commits a tax crime without written approval (nominee agreement), in addition to violating this Law, it also violates the provisions of the LLC Act.

4. Presidential Regulation on the Use of the Beneficial Ownership Principle in Combating and Eliminating Money Laundering and Terrorist Financing Crimes

Despite the fact that the primary goal of Presidential Regulation No. 13 of 2018 is to prevent and eradicate illegal money laundering and terrorism financing, the regulation does not rule out other criminal acts involving corporate beneficial owners, such as environmental crimes such as forestry and exploitation of natural resources; taxation; banking; human trafficking; drug abuse; and other offenses, including criminal acts of corruption as predicate offenses. It is also intended to close legal loopholes that have been identified in Act Number 8 of 2010 concerning the Prevention and Eradication of Money Laundering as well as Act Number 9 of 2013 concerning the Prevention and Eradication of the Crime of Terrorist Financing, both of which were enacted in the same year. The two statutes have previously addressed the issue of corporate liability, but they have yet addressed the issue of who is the beneficial owner of a company.
5. The Financial Services Authority's (OJK) Regulation onthe Implementation of Anti-Money Laundering and Terrorism Financing Prevention Programs in the Financial Services Sector

The current OJK regulation is Regulation No.23/POJK.01/2019, which was enacted on September 30, 2019, as an update to Regulation No.12/POJK.01/2017, which was enacted on March 21, 2017. Previously, the anti-money laundering and counter-terrorism financing regimes in the financial services industry were dispersed over various regulations, including OJK Regulations No.39/POJK.05/2015 for nonbank financial service providers and No.22/POJK.04/2014 for the market sector. Capital, followed by the Bank Indonesia Regulation No.14/27/PBI/2012 for commercial banks and No.12/20/PBI/2010 for rural banks and Sharia RuralBanks, as well as the Capital Market and Financial Institution Supervisory Agency (Bapepam-LK) No. Kep- 476/BL/2009 in the Capital Market sector.

6. Regulation of the Minister of Law and Human Rights Concerning the Procedures for Applying the Beneficial Ownership Principle to Corporations

Regulation No. 15 of 2019, which went into effect on June 27, 2019, is a follow-up to Presidential Decree No. 13 of 2018, which was promulgated in December 2018. The definition assigned to the term "beneficial owner" is, therefore, the same as that granted by Presidential Regulation No. 13 of 2018 on the subject of beneficial ownership.

\subsection{Accountability Of Beneficial Owners in Corruption Crimes}

Establishing the beneficial owner of a Limited Liability Company that has committed a criminal act of corruption is a tough task, but it is not impossible. Before proceeding with the remainder of the description, it is necessary to clarify that the term "beneficial owner" refers to an individual who has the ability to control all actions of the Limited Liability Company and its organs (directors, commissioners, and shareholders), even though he or she is not legally registered in the management, and who intends to commit the crime of corruption by using Limited Liability Company facilities in order to then enjoy the proceeds or profits of the crime, either directly or indirectly.

Thus, in order to hold the beneficial owner of the LLC responsible for the Corruption Crime, it is necessary to first classify the LLC as a criminal entity or as a suspect/defendant in a corruption case. This allows law enforcement to seize LLC assets in accordance with Article 18 of the Anti-Corruption Law. This is critical, because in order to ascertain 
who the true beneficiaries of crime are from a LLC that commits corruption, one cannot rely solely on the Criminal Procedure Code's paradigm of identifying a suspect (in personam), let alone 'hoping' that the LLC's management or organ will voluntarily disclose the beneficial owner's identity.

The recovery of stolen assets should always be prioritized in the process of law enforcement for criminal acts of corruption in the economic and financial sectors. If as many offenders as possible are sentenced to jail, and they are unable to recoup the damages suffered as a consequence of their conduct, the endeavor is pointless law enforcement and a waste of public funds. Every law enforcement process imposes costs on the state, and imprisoning the accused will almost certainly never have a deterrent effect as long as the proceeds or proceeds of the crime of corruption can be enjoyed by him in the future after his sentence is completed, or by his family or relatives while he is serving his sentence.

To apprehend a beneficial owner, all of LLC's assets must first be confiscated or frozen. NonConviction Based Asset Forfeiture/Seizure (NCB) refers to the confiscation of assets via a court procedure for criminal actions that do not need punishment. NCB starts with an investigation to gather the evidence needed to prove that an asset is the consequence or instrument of illegal conduct. Investigations may be conducted alone or in conjunction with criminal procedures. If the investigator/prosecutor is 'satisfied' with the evidence, a requestfor an order to freeze the assets is made to the Court in a short period. If the defendant does not appear in court to answer the summons, this may be done ex parte (in absentia). The Court's decision must be supported with justifications for the asset freeze, followed by the identification of the defendant. The NCB may potentially allow investigators more time to gather evidence and/or give suspects more time to prepare a case and establish the lawful origins of their assets. In addition, the Court must decide whether the assets should be restored to the defendant or given over to the State.[17]

It should be kept in mind while applying for NCB because disregarding criminal charges against defendants for the purpose of obtaining NCB may also damage the efficacy of criminal law and public trust in law enforcement officials. Although the NCB may be a useful instrument for recovering crimerelated assets, the NCB should not be utilized exclusively as a substitute for criminal prosecution where it is really feasible to prosecute the defendant. Instead, offenders should not be permitted to avoid prosecution by designating the NCB system as a tool for collecting assets as a consequence of crimes committed. In general, criminal prosecution, conviction, and confiscation are the most effective means of eradicating crime and its consequences Because of this, criminal prosecution must continue in order to prevent a situation in which the Public Prosecutor, the Courts of Justice and the general public consider the seizure of assets via the NCB to be an acceptable punishment when the criminal law is breached. As a result, the NCB is responsible for completing the defendant's criminal charges and penalties.[18]

It is virtually likely that the beneficial owner's closest associates or most trusted individuals are the LLC's directors, commissioners, and shareholders. Requiring a LLC that was purposefully formed to commit a crime by a beneficial owner tosubsequently apply the concept of beneficial ownership recognition as defined in Presidential Regulation No. 13 of 2018 and Ministerial Regulation No. 15 of 2019 is a tough task. It is almost difficult for a beneficial owner to transfer his property orassets to a person he does not know or trust to be used as LLC's capital. The directors, commissioners, and shareholders of the LLC are almost certainly members of the beneficial owner's family or close relatives. While it is true that this is an international provision governed by organizations such as the OECD, FATF, and G20, it is important to understand that the beneficial owner paradigm is not limited to himself as a legal owner, but also to legal arrangements that do not require official documents or legal.

Beneficial owner is undoubtedly concealed and unrecorded in the LLC's formation document. To ascertain the beneficial owner of a LLC that has committed a criminal act of corruption, it is necessary to track the movement of LLC assets (in rem). It is fair to assume that anybody who gets and enjoys money or property from the LLC is the beneficial owner. The issue is that the Anti-Corruption Law makes no specific reference to this subject. The most probable method of establishing a beneficial owner's criminal responsibility normatively is to use the instrument of anti-money laundering act.

By combining the anti-money laundering act with the concept of guiding mind and will in the theory of identification, one may simultaneously identify and hold both the LLC (corporate) and the beneficial owner responsible for their actions. In reality, the anti-money laundering act also specifies the responsibility of the beneficial owner, who is referred to as the corporate controlling people in Article 6 of the anti-money laundering act. In accordance with Article 1 number 14 of the antimoney laundering act, the beneficial owner can be determined to be a member of the corporation's controlling personnel, which is defined as "any person who has the power or authority to determine the Corporate policy or who has the authority to carry out the said Corporate policy without first 
obtaining authorization from his superiors."

The crucial phrase is "everyone who has the ability or responsibility to establish corporate policies, and so on." According to identification theory, this is what is meant by guiding mind and will, which refers to both the LLC controller as well as the organ. The anti-money laundering act does not even require that the controlling staff of a company be included in the corporation's deed of formation, as is required by most other jurisdictions. As long as the beneficial owner's primary goal is to benefit from the operations of the LLC that engages incorrupt practices, it is very likely that there will be a flow of money or assets held by the LLC that are enjoyed by the beneficial owner. As a result, it is apparent that by holding the LLC accountable in accordance with the requirements of the anti-money laundering act, it has the potential to indirectly hold the beneficial owner responsible.

In order to be able to ask for criminal liability of the beneficial owner of a LLC in a criminal act of corruption, the key to success lies with the Public Prosecutor, as the controller of the case. The Public Prosecutor may direct investigators to conduct a search for LLC assets if it is suggested (there is preliminary evidence) that an LLC committed a criminal act ofcorruption. The Public Prosecutor may then direct investigators to collaborate with the Financial Transaction Reports and Analysis Center (PPATK) in order to track the movement of money into and out of the LLC. Unless it is discovered, it is quite probable that by performing these things, the beneficial owner of the LLC will be identified, and then both the LLC and the beneficial owner would be held criminally liable under the approach of the anti-money laundering act and the identification doctrine.

In addition to the function of the Public Prosecutor inpreventing money laundering offenses, the gatekeeper plays a significant role in the investigation and prosecution of such crimes. Financial and legal professionals with specialized skills (for example, notaries, bankers, attorneys, and others) who haveknowledge of and easy access to the global financial system may use their well-honed competence to conceal the profits of corruption are examples of gatekeepers. This job is not inherently evil, but given the level of knowledge they possess, their career has the potential to be abused by unscrupulous officials

Financial Transaction Reports and Analysis Center's study report indicates that certain professions such as attorneys, notaries, property deed authorities, public accountants, and financial planners are particularly susceptible to being used by money laundering criminals in order to conceal the profits of their crimes. There are many gaps that these professional actors take advantage of that are linked to rules governing the confidentiality of professional interactions and service users, which are governed by various legislation and regulations. This scenario increases the awareness of nations across the globe that they should require professional reporting of unusual transactions from their service users in order to combat money laundering and other criminal activities.

The issues expressed are consistent with the FATF's beliefsabout the battle against corruption and money laundering throughout the globe. One of the most pressing recommendations of the FATF is that any profession that has a relationship with service users that are considered suspicious, or transactions carried out by service users that should be suspected of being criminal activities, has a professional responsibility to disclose such transactions. Financial Transaction Reports and Analysis Centre is the entity responsible for investigating suspicious financial transactions in Indonesia. This is governed by the Government Regulation (PP) No. 43 of 2015 concerning Reporting Parties in the Prevention and Eradication of the Crime of Money Laundering; and Regulation of the Head of the Financial Transaction Reports and Analysis Centre No. 11 of 2016 concerning Procedures for Submission of Suspicious Financial Transaction Reports for Professionals.

\section{CONCLUSION}

Because corruption is a kind of crime that occurs in the economic and financial sectors, it is critical to track down the assets that have been obtained via criminal activity in order to determine who is really benefiting from the profits of corruption. The purpose of LLC and its organs is primarily to provide the beneficial owner with a method of committing a crime. It is truethat they conceal their identities or do not register or are not recorded in the deed of formation of a LLC, but in reality, they have complete control over the LLC and its organs. In order to be able to identify the beneficial owner of the LLC who committed the crime of corruption, it is necessary to track the path taken by LLC assets as they move through the system (in rem). It is fair to infer that any individual who receives and enjoys money or property from the LLC is the beneficial ownerif that person is identified and identified. As a result, in order to hold the beneficial owner of the LLC responsible for corruption, it is necessary to first establish the LLC as a subject of criminallaw or as a suspect/accused, so that law enforcement officials may seize LLC assets in accordance with the AntiCorruption Law. Following that, law enforcement adopted a strategy based on the anti-money laundering act instrument to combat the crimes.

One of the challenges faced by law enforcement while attempting to identify the beneficial owner of a LLC that has committed a criminal act of 
corruption is obtaining information from LLC organs, such as the board of directors, the board of commissioners, and the shareholders of the LLC in question. As a result of their proximity to the beneficial owner of LLC, both as family and as relatives, they are more likely to defend him. A notary public is one of the most essential tools in determining who the beneficial owner of an LLC is (gatekeeper). In reality, law enforcement officers face significant challenges when attempting to get information and associated papers from notaries, mostly due to the fact that their responsibilities and activities are protected by the law. This can't be allowed to continue indefinitely. When a government's commitment has been poured into the shape of a policy, all of its components should work together to see that policy through to completion. As a result, it is recommended that the law that regulates notaries be repealed immediately. This law, in addition to regulating theprovision of information about the alleged beneficial owner in the establishment of an LLC to law enforcement (directly without going through the Ministry of Law and Human Rights), also stipulates sanctions, such as the revocation of licenses within a specified period of time, for a notary who intentionally or negligently approves the establishment of an LLC.

\section{ACKNOWLEDGMENT}

The author wishes to thank Attorney General's Office Jakarta,for providing the need to publish this Article

\section{REFERENCES}

[1] A. Meindl-Ringler, Beneficial Ownership in International Tax Law (Alphen aan den Rijn: Wolters Kluwer, 2016)

[2] B.A. Gardner, ed., Black's Law Dictionary, $2^{\text {nd }}$ Edition

(St. Paul, Minn.: West Group, 2001)

[3] British Institute of International and Comparative Law, "Can Non-Conviction based (NCB) asset forfeiture be compliant with the Rule of Law?" Briefing Paper, https://binghamcentre.biicl.org/documents/24_ briefing_paper.pdf

[4] E. Mazrieva, "ICIJ Releases Round Two Panama Documents", https://www.voaindonesia.com/a/icij-rilispanama-papers-babak-dua/3322323.html, accessed 29 January 2021

[5] Edwin Sutherland, "White-Collar Criminality", American Sociological Review 5, American No.1 (1940)

[6] F. Hagmann, "Beneficial Ownership - A Concept in Identity Crisis", Graduate Thesis,
Master of Laws Program Faculty of Law, Lund University, 2017

[7] FATF-OECD, FATF Guidance on Transparency and Beneficial Ownership (FATF Secretariat, 2014)

[8] Financial Transaction Reports and Analysis Center, 2016 Annual Report (Jakarta: PPATK, 2016)

[9] G. Widjaja, Trust Transplant in the Civil Code, Commercial Code and Indonesian Capital Market Law, Ed. 1 (Jakarta: Raja Grafindo Persada, 2008)

[10] H. Tanjaya, "A Legal Overview of the Shareholder Nominee Structure in a Limited Liability Company", Premise Law Jurnal, Vol. 6 (2016): 1. See Also Organisation for Economic Co-operation and Development, Behind the Corporate Veil: Using Corporate Entities for Illicit Purposes (Paris: OECD Publications Service, 2001)

[11] J. Hatchard, "Money Laundering: Public Beneficial Ownership Registers and The British Overseas Territories: The Impact of Sanction and Money Laundering Law 2018 (UK)", The Denning Law Journal 30, (2018)

[12] Kristian, "The Urgency of Corporate Criminal Liability",

Jurnal Hukum dan Pembangunan 44, No.4 (2013)

[13] M. Martini and M. Murphy, "Just for Show? Reviewing G20 Promise on Beneficial Ownership", (Transparency International, 2015)

[14] Ministry of Finance Fiscal Policy Agency, "Beneficial Owners in the OECD Model Tax Convention (MTC): History and Recent Developments", http://www.fiskal.kemenkeu.go.id/data/docume $\mathrm{nt} / 2012 / \mathrm{k}$

ajian/pkpn/Beneficial\%20Ownership\%20\%20Aplikasi\%20dalam\%20Tax\%20treaty.pdf, accessed 29 January 2021

[15] R.A. Posner, "Creating A Legal Framework for Economic Development", The World Bank Research Observer 13, No.1 (1998)

[16] S. Parsons, "The Doctrine of Identification, Causation and Corporate Liability for Manslaughter", The Journal of Criminal Law 67, Iss. 1 (2003)

[17] T.S. Greenberg, et al., Stolen Asset Recovery: A Good Practices Guide for Non-Conviction Based Asset Forfeiture (Washington, D.C.: The International Bank for Reconstruction and Development/The World Bank, 2009), 
[18] The International Consortium of Investigative Journalists (ICIJ), "Giant Leak of Offshore Financial Records Exposes Global Array of Crime and Corruption", http://www.icij.org/investigations/panamapapers/20160403-panama-papers-globaloverview/, accessed 29 January 2021

[19] W.B. Truit, The Corporation (Westport, Connecticut-London: Greenwood Press, 2006) 